\title{
KAJIAN USAHATANI PADI SAWAH DI PINGGIRAN KOTA: STUDI KASUS DI DESA HEGARMANAH, KECAMATAN JATINANGOR, KABUPATEN SUMEDANG
}

\author{
M. Gunardi Judawinata ${ }^{1}$ dan Yans Michael GRB Hutagalung ${ }^{2}$ \\ ${ }^{1}$ Departemen Sosial Ekonomi Pertanian, Fakultas Pertanian, Universitas Padjadjaran \\ ${ }^{2}$ Alumni Program Studi Agribisnis, Fakultas Pertanian, Universitas Padjadjaran
}

\begin{abstract}
ABSTRAK
Alih fungsi lahan di daerah sub-urban merupakan fenomena sosial yang sangat umum terjadi. Desa Hergamanah merupakan daerah sub-urban, yang terletak di kawasan sentra pendidikan dengan adanya beberapa universitas terkenal di Jawa Barat, menjadi lokasi yang rawan akan terjadinya alih fungsi lahan. Walaupun demikian, pertanian di daerah tersebut masih menjadi salah satu mata pencaharian bagi sebagian besar masyarakat. Tulisan ini bertujuan untuk mengetahui karakteristik petani, usahatani maupun alasan yang melatarbelakangi mereka untuk tetap bertahan di sektor pertanian. Pendekatan kualitatif digunakan dalam penelitian ini melalui studi kasus. Hasil penelitian menunjukkan bahwa usahatani padi sawah di Desa Hegarmanah cenderung menguntungkan, dengan karakteristik petani yang berumur produktif dan berlahan kecil. Walaupun demikian, terdapat beberapa keterbatasan dalam usahatani mereka seperti keterbatasan lahan, status penguasan lahan, permodalan dan pemasaran hasil. Diperlukan penelitian lebih lanjut untuk menggambarkan potensi dan kemungkinan perkembangan pertanian di lokasi tersebut di masa yang akan datang.
\end{abstract}

Kata kunci: alih fungsi lahan, pertanian, pembangunan, petani.

\section{ABSTRACT}

Sub urban areas are known to be suspectible to land transformation. Hegarmanah village is a sub urban area, due to its unique location as one of the education areas in West Java, which has caused the village to be affected by land transformation phenomenon. Though, agriculture sector still becomes one of income sources for Hegarmanah's population. This article aims to identify why are people still willing to farm in an area, where other sectors provide more lucrative opportunities, from socio economic perspectives. The research used mixed methods in order to get a complete perspective in answering the research questions. The results show that economically, the farm enterprises in Hegarmanah village are having good prospects with $R / C$ ratio larger than 1. Farmers characteristics are categorized as productive, small scale, and having good experience and knowledge in farming. However, it is inevitable that farmers are having more constraints in farming, which are mostly related to limited lands, monetary capital, and marketing. Further researchs are still needed in order to dig deeper to identify potencies and other possibilities for future agriculture development in Hegarmanah.

Keywords: land transformation, development, agriculture, farmers

\section{PENDAHULUAN}

Alih fungsi lahan pertanian selalu menjadi faktor pengancam dalam pembangunan pertanian di Indonesia. Irawan (2005) menyatakan bahwa terdapat dua faktor utama penyebab alih fungsi lahan, yaitu: 1) meningkatnya aksesibilitas yang menyebabkan meningkatnya pembangunan kawasan baik untuk pemukiman atau industry sehingga meningkatkan permintaan akan lahan; dan 2) peningkatan harga lahan yang menyebabkan banyak petani tergoda untuk menjual lahannya. Winoto (2005) menambahkan bahwa lahan sawah merupakan lahan yang paling rentan terkena dampak alih fungsi lahan, yang disebabkan oleh beberapa faktor seperti kepadatan penduduk di daerah pedesaan, karakteristik daerah sub-urban, pola dan rencana pembangunan pemerintah, dan topografi daerah.

Dalam penelitiannya, Winoto (2005) menunjukkan bahwa di Indonesia, rata-rata laju alih fungsi lahan sawah adalah 187.720 Ha per tahun, yang didominasi oleh pulau 
Jawa. Alih fungsi lahan pertanian tentu saja akan berdampak secara langsung maupun tidak langsung, terhadap kehidupan masyarakat sebagai produsen dan konsumen abadi pangan. Irawan (2005) menegaskan bahwa konversi lahan sawah ke penggunaan non pertanian seperti perumahan, kawasan industri, kawasan perdaganan, dan saran public dapat menimbulkan dampak negatif secara ekonomi, sosial, dan lingkungan termasuk mengancam ketahanan pangan baik dalam skala mikro maupun makro.

Di Kecamatan Jatinangor, Sumedang, percepatan alih fungsi lahan pertanian sudah mulai dapat dilihat dari data BPS (2015) yang menunjukkan terjadinya penurunan jumlah lahan sawah dari 2102 Ha pada tahun 2012, menurun menjadi 371 di tahun 2015. Dengan kata lain, dalam waktu 3 tahun, luas lahan sawah di Kecamatan Jatinangor menurun sebanyak $82,35 \%$. Hal ini menunjukkan bahwa pembangunan di Kecamatan Jatinangor terjadi dengan laju yang begitu cepat, sehingga menyebabkan alih fungsi lahan dengan laju yang begitu cepat.

Penyebab alih fungsi lahan di Kecamatan Jatinangor sangat terkait erat dengan pembangunan dan pengembangan kawasan Pendidikan seperti Universitas Padjadjaran (Unpad), Institut Koperasi Indonesia (Ikopin), Institut Pemerintahan Dalam Negeri (IPDN), Universitas Winayamukti (Unwim) yang sekarang pengelolaan manajemennya beralih dari Pemerintah Daerah Jawa Barat ke Institut Teknologi Bandung (ITB). Observasi awal menunjukkan bahwa masih ada lahan pertanian di Desa Hegarmanah, khususnya lahan sawah. Dinamika pembangunan di daerah ini berjalan dengan sangat cepat sehingga menyebabkan alih fungsi lahan pertanian yang berdampak pada perubahan struktur mata pencaharian dari pertanian ke non pertanian, atau sektor primer ke sektor sekunder maupun ke sektor tersier seperti jasa.

Meskipun demikian, tidak dapat dipungkiri bahwa masih ada sebagian warga yang memilih untuk tetap menjadikan sektor pertanian sebagai sumber matapencaharian mereka. Oleh karena itu, penelitian ini bertujuan untuk mengetahui secara lebih dalam karakteristik pelaku usahatani, alasan mereka masih mengusahakan padi sawah, Teknik budidaya yang dilakukan, pemasaran hasil, dan analisis usahatani di daerah suburban Desa Hegarmanah.

\section{METODE PENELITIAN}

Penelitian ini menggunakan pendekatan mixed methods yang memadukan penggunaan teknik kualitatif dan kuantitatif. Hal ini dilakukan sebagai langkah dalam rangka mendapatkan gambaran yang komprehensif dalam mencapai tujuan dari penelitian ini. Analisis deskriptif kualitatif dilakukan melalui penyampaian interpretasi data primer yang didudukan pada suatu konsep atau teori. Analisis deskriptif kualitatif ini digunakan untuk menjawab pertanyaan yang sifatnya personal, yang hanya dapat diperloleh dari hasil kajian yang mendalam.

Analisis kuantitatif digunakan untuk menganalisis usahatani dengan menggunakan konsem Return Cost Ratio, yang bertujuan untuk mencari tingkat keuntungan pelaku usahatani. Menurut Soekartawi (2006), Return Cost Ratio adalah perbandingan antara penerimaan dengan biaya. Secara teoritis, dengan rasio $\mathrm{R} / \mathrm{C}=1$ menunjukkan bahwa suatu usaha mencapai Break Even Point, di mana kerugian maupun keuntungan tidak dialami. Secara matematik, hal ini diturunkan dalam rumus:

$$
\begin{gathered}
\mathrm{a}=\mathrm{R} / \mathrm{C} \\
\mathrm{R}=\mathrm{Py} . \mathrm{Y} \\
\mathrm{C}=\mathrm{FC}+\mathrm{VC} \\
\text { Sehingga } \mathrm{a}=[(\mathrm{Py} . \mathrm{Y}) /(\mathrm{FC}+\mathrm{VC})]
\end{gathered}
$$

Keterangan:

$\mathrm{R}=$ Penerimaan

$\mathrm{C}=$ Biaya

Py = Harga Output

$\mathrm{Y}=$ Jumlah Output

$\mathrm{FC}=$ Biaya Tetap

$\mathrm{VC}=$ Biaya Variabel

Menurut Rodjak (2006), hubungan antara penerimaan $(\mathrm{R})$ dengan biaya $(\mathrm{C})$ bisa menunjukkan beberapa kemungkinan sebagai berikut:

1. Biaya usahatani lebih besar dari penerimaan, maka usahatani disebut rugi

2. Penerimaan usahatani lebih besar daripada biaya usahatani, maka usahatani disebut untung

3. Biaya usahatani sama dengan penerimaan, maka usahatani tersebut dinyatakan tidak untung dan tidak rugi, atau dalam keadaan titik impas (Break Even Point) 
Teknik penentuan responden dalam penelitian ini dilakukan secara purposive dan snowball sampling (non-probability sampling) dengan cara sebagai berikut:

1. Melakukan penelusuran di Desa untuk mengidentifikasi lokasi usahatani padi sawah,

2. Melakukan penentuan dan pengukuran lokasi sawah menggunakan alat GPS, lalu diolah menggunakan perangkat lunak ArcGis,

3. Membuat peta berdasarkan data yang telah diolah,

4. Mengidentifikasi petani pada setiap lokasi sawah,

5. Menentukan responden menggunakan prinsip snowball sampling, dengan kriteria sebagai berikut:

a. Responden berada di lokasi penelitian

b. Responden bersedia untuk memberikan informasi yang dibutuhkan

c. Responden dapat berbahasa Indonesia

d. Responden memiliki dan mengusahakan lahan sawah.

\section{HASIL PENELITIAN}

Desa Hegarmanah merupakan pemekaran dari Desa Cikeruh pada tahun 1983. Wilayah tersebut memiliki topografi yang berbukit-bukit dengan permukaan tertinggi 705 DPL dan permukaan terendah 700 DPL. Curah hujan di desa Hegarmanah sebesar $1320 \mathrm{~mm} /$ tahun dengan suhu udara rata-rata $30{ }^{\circ} \mathrm{C}$. Dengan karaktersitik geografis tersebut, maka daerah tersebut sangat cocok untuk ditanami padi. Walaupun demikian, karakteristik wilayah Desa Hegarmanah yang merupakan daerah sub-urban dan sentra Pendidikan, telah menimbulkan ancaman terhadap sektor pertanian di wilayah tersebut. Di sisi lain, karakteristik wilayah sub-urban juga memiliki potensi untuk mendukung kegiatan pertanian apabila dapat diintegrasikan dengan potensi ekosistem wilayah tersebut, dan dikelola secara baik dengan tujuan yang selaras dengan pembangunan pertanian. Salah satu contoh potensi yang dapat dikembangkan adalah kedekatan lokasi dengan kota-kota besar (Bandung dan Sumedang), dengan jarak kurang dari 25 Kilometer. Hal ini berarti lokasi tersebut sebetulnya memiliki keuntungan berupa akses terhadap pasar yang lebih mudah untuk dicapai. Iwan (2006) mengutarakan bahwa akses yang tinggi dapat didasarkan pada jarak lokasi ke pusat-pusat pelayanan public yang identik dengan ibukota propinsi dan ibukota kabupaten.

Apabila dilihat dari data profil desa, maka tata guna lahan di Desa Hegarmanah saat ini didominasi oleh perumahan, seperti yang dapat dilihat dalam tabel di bawah ini:

Tabel 1.

Tata Guna Lahan Desa Hegarmanah 2015

\begin{tabular}{lll}
\hline Tata Guna & Luas (Ha) & Persentase (\%) \\
\hline Perumahan & 200,40 & 60,54 \\
Sawah & 86,82 & 26,23 \\
Ladang/Tegalan & 36,85 & 11,13 \\
Kuburan & 0,90 & 0,27 \\
Kantor Desa & 0,88 & 0,27 \\
Lapangan & 1,80 & 0,54 \\
Perkantoran & 3,35 & 1,01 \\
Pemerintah & & \\
Jumlah & 331,00 & 100,00 \\
\hline \multicolumn{2}{l}{ Sumber: Profil }
\end{tabular}

Sumber: Profil Desa Hegarmanah 2016

Berdasarkan wawancara dengan Kaur Perencanaan Desa, dampak dari berkembangnya kawasan Pendidikan di sekitar wilayah Desa Hegarmanah adalah sebagai berikut:

a. Lahan pertanian hanya tersisa kurang dari $30 \%$ dari total luas lahan desa dan umumnya berlokasi di wilayah selatan desa. Dorongan terjadinya perubahan ini disebabkan oleh daya terik ekonomi ketika lahan pertanian bertransformasi menjadi non-pertanian. Fenomena ini beliau ungkapkan dalam Bahasa Sunda sebagai berikut:

"Mending panén sataun sakali daripada panén tilu kali sataun, ku lantaran panén sataun sakali mah hasil na bisa jang indit umroh"

Dengan arti:

"Lebih baik menjual lahan usahataninya untuk dijadikan tempat kos karena uang yang didapat setaun sekali lebih besar dibandingkan dengan hasil panen padi sawah yang meski 3 kali dalam satu tahun, tetapi hanya cukup untuk memenuhi kebutuhan hidup sehari-hari"

b. Perubahan tersebut membawa konsekwensi terhadap status sosial dan gaya hidup masyarakat Desa Hegarmanah, karena perubahan struktur mata pencaharian dari sektor pertanian ke nonpertanian ikut memberikan kontribusi pada peningkatan pendapatan. Sebagai contoh, 
seorang petani padi sawah sebelumnya menambah pendapatan keluarga dengan melakukan pekerjaan sampingan. Tetapi sekarang, mereka bisa menjadi 'juragan kos' atau membuka usaha sendiri dengan modal hasil menjual tanah. Hal ini tentu saja berpengaruh pada gaya hidup dan kohesi sosial di masyarakat.

Fenomena tersebut diperkuat oleh keterangan yang didapat dari aparat dan tokoh masyarakat di Desa Hegarmanah yang menyatakan bahwa perubahan tersebut ikut memengaruhi sikap dan partisipasi masyarakat terhadap kegiatan kemasyarakatan seperti gotong-royong dan ronda. Jika jaman dulu masyarakat sangat antusias berpartisipasi dalam kegiatan kemasyarakatan, saat ini mereka lebih mengandalkan partisipasi dalam bentuk bantuan materi (uang). Dengan kata lain, perubahan-perubahan tersebut telah membuat jarak dan kesenjangan sosial di masyarakat Desa Hegarmanah. Perubahan juga terjadi pada mata pencaharian utama dari penduduk desa, yang saat didominasi oleh sektor perdagangan dan jasa. Hal tersebut terjadi karena lapangan pekerjaan yang tersedia, niat generasi muda yang tidak lagi tertarik dengan sektor pertanian, dan ada kecenderungan perubahan gaya hidup ke arah konsumtif, instan, dan gengsi, sehingga mengurangi etos kerja keras.

Secara umum, fenomena dan fakta yang terjadi di Desa Hegarmanah sejalan dengan benang merah dari pemikiran para ahli sosiologi seperti Ferdinand Tõnnies, Emile Durkheim, dan Max Weber tentang masyarakat pedesaan. Pemikiran tersebut menyatakan bahwa setiap tipe ang ada dibedakan atas dasar kualitas dan jenis relasi sosial yang terbangun dalam suatu masyarakat, di samping perbedaan ciri fisik dan demografisnya. Kualitas dan jenis relasi sosial yang ada dalam Gemainschaft, beririsan besar dengan solidaritas mekanik dan masyarakat agraris tradisional. Demikian pula dengan kualitas dan jenis relasi sosial yang ada dalam Gesellshaft, irisan yang luas dengan kualitas dan jenis relasi yang terbangun dalam solidaritas organic dan masyarakat industry. Selanjutnya, Sanderson (2003) menyatakan bahwa masyarakat agraris merupakan masyarakat pertanian berskala besar dengan peralatan bajak dan binatang penarik.

Fenomena di Desa Hegarmanah cenderung masuk ke dalam kategori daerah transisi, karena beberapa indikator pedesaan sudah mulai tererosi. Lahan pertanian kurang dari $30 \%$, sektor mata pencaharian mulai bergeser dari sektor primer ke sektor sekunder dan tersier, aspek kependudukan berubah, hubungan interaksi seperti bentuk solidaritas dan kohesi sosial masyarakat berkurang, dan gaya hidup serta aksesibilitas sudah menyerupai konsep perkotaan walaupun secara administrative masih menggunakan penamaan desa.

\section{Karakteristik Petani dan Usahatani}

Berdasarkan hasil survey, didapatkan petani di Desa Hegarmanah didominasi oleh petani tua, dengan umur 40-64 tahun $(87,5 \%)$ dan di atas 65 tahun (12,5\%). Dengan demikian, dapat dikatakan bahwa petani padi sawah di Desa Hegarmanah termasuk dalam kategori usia produktif. Meskipun demikian, apabila dilihat secara lebih lanjut, umur petani termuda adalah 40 tahun. Selain dari itu, apabila merujuk pada Soekartawi (2006), petani muda biasanya mempunyai semangat untuk ingin tahu apa yang belum mereka ketahui, sehingga mereka lebih cepat dalam proses adopsi inovasi. Soekartawi (2006) juga mengkategorikan petani muda sebagai petani yang memiliki umur antara 16-30 tahun. Dengan demikian, Desa Hegarmanah masuk ke dalam kriteria produktif, tetapi usia produktifnya tidak termasuk dalam kategori petani muda. Hal ini menunjukkan adanya resiko kegagalan dalam regenerasi sumber daya manusia pertanian di masa yang akan datang, yang dapat menjadi ancaman yang serius bagi sektor pertanian di Desa Hegarmanah dalam 10-20 tahun ke depan.

Berdasarkan tingkat Pendidikannya, responden cenderung berada pada kategori menengah ke bawah, karena lebih dari $80 \%$ dari responden hanya mengenyam Pendidikan sampai tingkat Sekolah Dasar dan Sekolah Menengah Pertama. Menurut informasi yang didapat dari responden, kurang berkembangnya tingkat Pendidikan dikarenakan para orangtua cenderung menyekolahkan anaknya hanya sampai jenjang SD atau SMP saja. Hal tersebut disebabkan para orang tua cenderung mempunyai harapan agar dapat segera bekerja di sawah untuk membantu orangtuanya. Selain itu, faktor biaya menjadi faktor utama yang membatasi tingginya Pendidikan responden. Hal tersebut sejalan dengan pendapat Setiawan (2012) yang mengatakan bahwa sebagian besar keluarga 
petani masih sulit untuk menyekolahkan anakanaknya ke jenjang Pendidikan yang lebih tinggi, karena untuk memenuhi modal usahatani dan kehidupan sehari-hari nya saja masih terasa sulit.

Jika dilihat dari status penguasaan lahan, $75 \%$ dari responden merupakan petani penyewa, sedangkan $25 \%$ merupakan petani pemilik dan penggarap. Hal ini juga merupakan imbas dari proses pembangunan yang begitu cepat, sehingga banyak petani yang menjual lahannya kepada orang dari luar daerah (investor dari daerah perkotaan) dan menjadi buruh di tempat sendiri. Hal ini tentu saja berpengaruh pada daya tarik sektor pertanian di Desa Hegarmanah secara keseluruhan. Penurunan jumlah petani dengan status sebagai pemilik lahan telah menyebabkan sektor pertanian menjadi lebih identik dengan buruh, yang oleh generasi muda dianggap sebagai pekerjaan yang dilakukan oleh kaum rendah.

Analisis Usahatani. Perhitungan Analisis Usahatani padi sawah petani responden diperoleh dari perbandingan antara penerimaan dengan biaya produksi.

Penerimaan adalah perkalian antara hasil produksi dengan harga jual, sedangkan biaya produksi adalah jumlah keseluruhan biaya tetap dan biaya variable. Analisis usahatani tersaji dalam tabel 2 berikut:

Tabel 2.

Daftar Analisis R/C Ration Informan Kunci

\begin{tabular}{lll}
\hline \multicolumn{1}{c}{ Responden } & \multicolumn{1}{c}{ Keuntungan (Rp.) } & R/C \\
\hline Dasih & $3.960 .000,00$ & 3,6 \\
Endang & $3.176 .000,00$ & 3,1 \\
Nunung & $2.883 .000,00$ & 2,9 \\
Ukin & $1.645 .000,00$ & 2,2 \\
Sunjali & $3.942 .000,00$ & 3,5 \\
Wawan & $2.947 .000,00$ & 3,0 \\
Ombi & $4.160 .000,00$ & 4,1 \\
Eman & 2.395.000,00 & 3,0 \\
\hline \multicolumn{3}{c}{ Rata-rata } \\
\hline
\end{tabular}

Sumber: Data primer, diolah (2017)

Pada tabel di atas dapat dilihat bahwa nilai rata-rata $\mathrm{R} / \mathrm{C}$ ratio petani responden lebih dari 1. Dengan kata lain, seluruh responden mengalami keuntungan rata-rata 3 kali lipat dari modal yang dikeluarkan. Apabila dilihat dari sudut pandang ekonomi sederhana, maka usahatani tersebut sangat layak untuk diusahakan. Walaupun demikian, apabila ditelusuri secara lebih detail, maka dapat dilihat bahwa petani responden hanya mendapat keuntungan dengan rata-rata sekitar 2 juta rupiah dalam satu musim. Dengan kata lain, apabila dikonversikan ke dalam penghasilan bulanan, maka mereka hanya memperoleh penghasilan kuran dari 1 juta rupiah per bulan nya. Fakta tersebut apabila disandingkan dengan situasi dan kondisi sosial yang menunjukkan cepatnya laju pembangunan sehingga kesempatankesempatan usaha lain yang lebih menguntungkan bermunculan, maka akan terlihat sangat wajar apabila sektor pertanian mulai ditinggalkan oleh masyarakat setempat.

\section{Motivasi}

Dari uraian-uraian di atas, maka dapat dilihat adanya kesenjangan dalam fenomena dinamika sosial di Desa Hegarmanah. Pertama, karakteristik petani dan usahatani yang menunjukkan ketidakmampuan sektor pertanian dalam menopang dan mengembangkan kesejahteraan masyarakat; dan kedua, fakta masih terdapatnya masyarakat yang memilih untuk bertahan di sektor primer. Kontradiksi kondisi tersebut mengarah pada satu analisis yang dapat menjelaskan fenomena sosial yang terjadi di Desa Hegarmanah.

Tabel 3.

Alasan Informan Desa Hegarmanah Bertahan di Bidang Pertanian

\begin{tabular}{|c|c|c|c|}
\hline $\begin{array}{l}\text { Respon- } \\
\text { den }\end{array}$ & $\overline{\text { Umur }}$ & $\begin{array}{c}\text { Status } \\
\text { Penguasa- } \\
\text { an Lahan } \\
\end{array}$ & $\begin{array}{l}\text { Alasan Bertahan di } \\
\text { Pertanian }\end{array}$ \\
\hline Dasih & 64 & Penyewa & $\begin{array}{l}\text { Keterbatasan modal } \\
\text { untuk usaha non- } \\
\text { pertanian }\end{array}$ \\
\hline Endang & 60 & Penyewa & $\begin{array}{l}\text { Faktor umur dan } \\
\text { keterbatasan } \\
\text { kemampuan }\end{array}$ \\
\hline Nunung & 57 & Penyewa & $\begin{array}{l}\text { Berusahatani padi } \\
\text { merupakan pekerjaan } \\
\text { turun-temurun }\end{array}$ \\
\hline Ukin & 70 & Penyewa & $\begin{array}{l}\text { Kemampuan yang } \\
\text { dimiliki hanya bertani }\end{array}$ \\
\hline Sunjali & 43 & Penyewa & $\begin{array}{l}\text { Kemampuan yang } \\
\text { dimiliki hanya bertani }\end{array}$ \\
\hline Wawan & 53 & Penyewa & $\begin{array}{l}\text { Kemampuan yang } \\
\text { dimiliki hanya bertani }\end{array}$ \\
\hline Ombi & 58 & Pemilik & $\begin{array}{l}\text { Kemampuan yang } \\
\text { dimiliki hanya bertani }\end{array}$ \\
\hline Eman & 52 & Pemilik & $\begin{array}{l}\text { Kemampuan yang } \\
\text { dimiliki hanya bertani }\end{array}$ \\
\hline
\end{tabular}

Menurut Danim (2012), motivasi dapat diartikan sebagai kekuatan, dorongan, kebutuhan, semangat, dan tekanan yang dapat 
mendorong seseorang untuk mencapai tujuan tertentu. Dalam konteks penelitian ini, yang dimaksud motivasi petani adalah alasan petani untuk tetap menjadikan sektor pertanian sebagai mata pencaharian mereka.

Berdasarkan hasil penelitian, seluruh responden menyatakan untuk tetap berusahatani dengan alasan keterbatasan yang dimiliki, baik dari faktor modal, umur, kemampuan dan pengalaman, serta budaya. Hal ini berlaku tanpa terkait dengan umur maupun status penguasaan lahan responden. Perkembangan wilayah Desa Hegarmanah yang bergeser dari sektor pertanian ke nonpertanian, ternyata cenderung menjadi dorongan bagi para petani untuk tetap menjadikan sektor pertanian sebagai mata pencaharian mereka. Kesimpulan dari hasil wawancara dapat dilihat pada tabel 3 berikut:

Motivasi petani dapat dilihat dari sisi sosial dan ekonomi petani tersebut. Beberapa petani di Desa Hegarmanah memiliki lahan yang tergolong sempit. Dari hasil observasi didapatkan bahwa jumlah tanggungan per keluarga tergolong besar, akan tetapi karena Desa Hegarmanah merupakan daerah yang cukup berkembang, maka tersedia banyak lapangan pekerjaan untuk anak-anak mereka, sehingga dapat membantu ekonomi keluarga.

Motivasi petani dari segi sosial meliputi umur petani yang masih produktif, serta pengalaman usahatani yang cukup lama.

Menurut pendapat Maslow, ada kebutuhan internal yang sangat memengaruhi motivasi manusia dalam bekerja. Maslow berpendapat bahwa kebutuhan tersebut disusun sebagai hierarki yang terdiri atas lima kebutuhan yang sifatnya berjenjang. Jika kebutuhan pertama telah terpenuhi, orang akan berusaha mencapai pemenuhan kebutuhan kedua, dan seterusnya. Teori hierarki kebutuhan apabila disandingkan dengan teori perbedaan karakteristik pelaku usahatani dari Redfield, maka dapat disimpulkan bahwa petani padi sawah Desa Hegarmanah termasuk ke dalam kategori petani tradisional.

\section{KESIMPULAN}

Petani di Desa Hegarmanah didominasi oleh petani penyewa yang masih cenderung produktif, tetapi dari segi luas lahan garapannya termasuk petani kecil dengan status Pendidikan menengah kebawah, sehingga tergolong dalam petani tradisonal. Motivasi petani padi sawah di Desa
Hegarmanah masih bertahan melaksanakan usahatani padi sawah karena tidak memiliki pengetahuan tentang bidang lain dan tidak memiliki modal yang cukup untuk usaha lain, sedangkan minat generasi muda di Desa Hegarmanah terhadap bidang pertanian khususnya tanaman padi sawah cenderung rendah, sehingga petani masih melakukan usahatani padi sawah hanya untuk memenuhi kebutuhan sehari-hari.

Teknik budidaya tanaman padi sawah di Desa Hegarmanah cenderung tergolong tidak tradsional, karena petani cenderug sudah melakukan beberapa tahapan budidaya sesuai anjuran. Pemasaran hasil produksi tani di Desa Hegarmanah cenderung tradisional karena petani menjual hasil panennya kepada tengkulak yang hubungannya bersifat patronklien, hal ini disebabkan petani kadang kala memerlukan bantuan untuk dapat mencukupi kebutuhan sehari-hari dan modal produksi yang diperoleh dari tengkulak. Berdasarkan analisis usahatani padi sawah di Desa Hegarmanah diperoleh hasil rata-rata $\mathrm{R} / \mathrm{C}$ ratio lebih dari 1, sehingga usahatani tersebut termasuk menguntungkan.

Walaupun demikian, keberlangsungan usaha tidak dapat dinilai hanya dari $\mathrm{R} / \mathrm{C}$ ratio. Meski nilai rata-rata $\mathrm{R} / \mathrm{C}$ ratio para petani sebesar 3,2, tetapi bila melihat skala usaha dan perputaran uang dari usaha mereka, maka para petani di Desa Hegarmanah memiliki penghasilan yang rendah. Selain itu, alasan mereka untuk bertahan di bidang pertanian didominasi dasar keterbatasan (lahan, modal, dan pengetahuan). Dengan kata lain, apabila mereka tidak memiliki keterbatasan-keterbatasan tersebut, maka mereka akan memilih profesi lain yang lebih menguntungkan dan mampu menjamin masa depan keluarganya.

Fenomena tersebut menjadi cermin betapa miris kondisi pertanian di daerah suburban. Pertanyaan yang harus dijawab oleh penelitian selanjutnya adalah apakah mungkin pertanian terus dipertahankan sebagai mata pencaharian utama warga desa Hegarmanah? Atau mungkin memang sudah waktunya warga diberdayakan untuk beralih profesi, demi terjaganya kesejahteraan warga Desa Hegarmanah dan mempersempit kesenjangan sosial sebagai dampak dari pembangunan.

\section{DAFTAR PUSTAKA}

Irawan, B. 2005. Konversi Lahan Sawah: Potensi Dampak, Pola Pemanfaatan, dan 
Faktor Determinan. Forum Penelitian Agro-Ekonomi Volume 23 Nomor 1, Juni 2005. Pusat Analisis Sosial Ekonomi dan Kebijakan Pertanian. Bogor

Badan Pusat Statistik Jawa Barat. 2014. Statistik Lahan Pertanian 2014. Jawa Barat.

Badan Pusat Statistik Sumedang. 2015. Statistik Lahan Pertanian 2015. Sumedang

Mendras, Henri. 1995. Les société paysannes: Éléments pour une théorie de la paysannerie. Édition Gallimard, 1995 (L'édition originale de cet ouvrage a été publiée en 1976 par le éditions Armand Colin)
Rodjak, Abdul. 2006. Manajemen Usaha Tani. Jilid II. Bandung: Pustaka Gratuna.

Setiawan, Iwan. 2006. Analisis Akses DesaDesa di Kabupaten Bandung Terhadap Sumber-Sumber Produktif: Suatu Analisis Dengan Pendekatan Integrated Rural Accessibility Planning. Hasil Penelitian Jurusan Sosial Ekonomi Fakultas Pertanian Universitas Padjadjaran. Bandung

Soekartawi. 2006. Analisis Usahatani. UIPress. Jakarta.

Winoto. 2005. Strategi Pengendalian Alih Fungsi Lahan Pertanian Bertumpu Pada Partisipasi Masyarakat. Bogor 